\title{
Analisis Efektivitas E-LKPD (Lembar Kegiatan Peserta Didik Elektronik) Berbasis Etnomatematika Batu Akik Ditinjau dari Kemampuan Awal Siswa
}

\author{
Dafid Slamet Setiana ${ }^{1 *}$, Nuryadi ${ }^{2}$ \\ ${ }^{1}$ Universitas Sarjanawiyata Tamansiswa, Yogyakarta 55165, DIY, Indonesia \\ ${ }^{2}$ Universitas Mercu Buana Yogyakarta, Bantul 55753, DIY, Indonesia
}

Pengiriman: 10/Juli/2021; Diterima: 24/September/2021; Publikasi: 30/September/2021

DOI: https://doi.org/10.31629/jg.v6i2.3566

\begin{abstract}
Abstrak
Penelitian ini bertujuan untuk menganalisis efektivitas e-LKPD berbasis etnomatematika terhadap hasil belajar matematika yang ditinjau dari kemampuan awal siswa, serta untuk mengetahui pengaruh interaksi antara jenis eLKPD dan tingkat kemampuan awal siswa terhadap hasil belajar matematika. Jenis penelitian yang digunakan yaitu penelitian eksperimen semu. Subjek uji coba penelitian adalah siswa kelas IV SDN Sukodono 1 dan SDN Sukodono 2 Kecamatan Donorojo, Kabupaten Pacitan dengan masing-masing kelas diambil sampel secara acak sebanyak 15 siswa. Adapun objek penelitian ini adalah kemampuan awal dan hasil belajar matematika siswa. Teknik pengumpulan data yang digunakan adalah teknik tes dan teknik dokumentasi. Data dianalisis dengan anava dua faktor, dimana faktor pertama adalah jenis e-LKPD dan faktor kedua adalah tingkat kemampuan awal siswa. Hasil analisis anava dua faktor pada taraf signifikansi 5\% menunjukkan bahwa: 1) e-LKPD berbasis etnomatematika lebih efektif daripada e-LKPD konvensional. (2) Hasil belajar siswa dengan tingkat kemampuan awal tinggi lebih baik daripada siswa yang memiliki kemampuan awal sedang dan rendah, dan (3) tidak ada interaksi antara jenis e-LKPD dan tingkat kemampuan awal siswa berdasarkan hasil belajar matematika siswa.
\end{abstract}

Kata kunci: efektivitas; e-LKPD; kemampuan awal

\begin{abstract}
This study aims to analyze the effectiveness of ethnomathematics-based e-LKPD on mathematics learning outcomes in terms of students' initial abilities, as well as to determine the effect of interactions between types of e-LKPD and students' initial ability levels on mathematics learning outcomes. The type of research used is quasi-experimental research. The research subjects used as test subjects were fifth grade students of SD Negeri Sukodono 1 and SD Negeri Sukodono 2, Donorojo District, Pacitan Regency. The object of this research is the initial ability and learning outcomes of students' mathematics. Data collection techniques used are test techniques and documentation techniques. The data were analyzed using two-factor ANOVA, where the first factor was the type of e-LKPD and the second factor was the initial ability level of the students. The results of two-factor ANOVA analysis at a significance level of 5\% show that: 1) ethnomathematics-based e-LKPD is more effective than conventional e-LKPD. (2) The learning outcomes of students with high initial ability levels are better than students with medium and low initial abilities, and (3) there is no interaction between the type of e-LKPD and students' initial ability levels based on students' mathematics learning outcomes.
\end{abstract}

Keywords: effectiveness; e-LKPD; initial ability

*Penulis Korespondensi

Email Address: dafid.setiana@ustjogja.ac.id

Handphone $\quad$ : +6285879939967 


\section{JURNAL GANTANG. September 2021; VI(2): 113 - 123 \\ p-ISSN. 2503-0671 \\ e-ISSN. 2548-5547}

\section{Pendahuluan}

Pandemi Covid-19 mengharuskan adanya berbagai kebijakan untuk memutuskan mata rantai penyebaran virusnya. Salah satu upaya yang cukup berpengaruh untuk memutuskan mata rantai penyebaran virus adalah dengan melakukan pembatasan interaksi masyarakat yang diterapkan dengan istilah physical distancing. Namun, kebijakan tersebut dapat menghambat laju pertumbuhan dalam berbagai bidang kehidupan, baik bidang ekonomi, sosial, dan tentu saja pendidikan.

Pemerintah menerapkan kebijakan yaitu work from home (WFH). Kebijakan WFH tertuang dalam Surat Edaran Menteri Pendayagunaan Aparatur Negara dan Reformasi Birokrasi (PAN \& RB) Nomor 50/2020 tentang Perubahan Kedua atas Surat Edaran Menteri PAN \& RB Nomor 19/2020 tentang Penyesuaian Sistem Kerja Aparatur Sipil Negara dalam Upaya Pencegahan Penyebaran Covid-19 di Lingkungan Instansi Pemerintah. Kebijakan ini merupakan upaya yang diterapkan kepada masyarakat agar dapat menyelesaikan segala pekerjaan di rumah.

Pendidikan di Indonesia menjadi salah satu bidang yang terdampak akibat adanya pandemi Covid-19. Dengan adanya pembatasan interaksi, Kementerian Pendidikan dan Kebudayaan Indonesia juga mengeluarkan kebijakan dengan istilah Belajar dari Rumah (BDR), di mana proses pembelajaran dilaksanakan di tempat tinggal masing-masing dengan menggunakan sistem dalam jaringan (daring). Dasar pelaksanaan kegiatan tersebut yaitu Surat Edaran Mendikbud No. 4 Tahun 2020 tentang pelaksanaan kebijakan dan pendidikan dalam masa darurat penyebaran virus.

Pembelajaran daring dapat dikatakan sebagai satu-satunya alternatif pembelajaran pada masa pandemi. Meski demikian pembelajaran daring juga memiliki beberapa kekurangan, dimana hal ini dapat menimbulkan ancaman putus sekolah dan berpengaruh terhadap kesenjangan prestasi belajar (Kemdikbud, 2020). Dalam pembelajaran daring, setiap unsur pendidikan dituntut untuk dapat memfasilitasi pembelajaran agar tetap aktif (Setyorini, 2020). Oleh karena itu, untuk memenuhi kebutuhan pembelajaran daring diperlukan bahan ajar yang dapat disampaikan melalui jaringan internet, salah satunya adalah eLKPD (Lembar Kerja Peserta Didik Elektronik).

E-LKPD pada hakikatnya sama dengan LKPD pada umumnya, hanya saja e-LKPD tidak dicetak pada lembaran kertas, namun hanya berbentuk soft file yang dapat diakses melalui smartphone maupun laptop dan komputer. Peneliti mengangkat budaya lokal di Desa Sukodono, Kecamatan Donorojo, Kabupaten Pacitan berupa kerajinan batu akik sebagai media dalam pembelajaran matematika. Batu akik atau batu permata adalah mineral-mineral yang telah terbentuk dalam kondisi alam yang berbeda pada perut bumi. Mineral memiliki komposisi kimiawi tertentu dan memiliki susunan atom yang beraturan, sehingga memiliki sifat-sifat fisik dan optik yang relatif konstan atau tetap. Menurut referensi lain batu akik adalah batu yang tercipta karena proses alam yang sangat lama dari pengendapan fosil dan pembentukan mineral yang berpadu menjadi sebuah batu akik atau permata.

Sebuah batu disebut akik atau permata apabila memenuhi beberapa syarat, antara lain memiliki ketahanan, keindahan, dan kelangkaan. Di Indonesia ada banyak daerah yang menghasilkan ragam batu akik atau batu permata populer. Salah satu daerah pengrajin batu akik di Pulau Jawa yang cukup terkenal yaitu di Kecamatan Donorojo, Kabupaten Pacitan. Aadapun macam-macam batu akik antara lain: amber, Beril atau zamrud (emerald), Berlian (diamond), Giok (jade), ruby, kecubung, pirus, onyx, bacan, topaz, Opal atau Kalimaya, obsidian, dan Zircon. Batu akik yang memiliki bentuk beragam memiliki potensi untuk diintegrasikan ke dalam materi pembelajaran matematika.

Belum pernah adanya penelitian terkait etnomatematika batu akik dan didukung oleh adanya semangat melestarikan budaya lokal, maka peneliti berusaha memanfaatkan potensi etnomatematika pada batu akik ke dalam pembelajaran melalui pengembangan e-LKPD. Pada penelitian sebelumnya telah dilaksanakan pengembangan e-LKPD soal cerita berbasis 
etnomatematika batu akik. E-LKPD yang dikembangkan memuat langkah-langkah penyelesaian soal cerita pada materi operasi hitung campuran. Soal cerita matematika adalah soal yang berhubungan dengan kehidupan seharihari yang merupakan terapan dari suatu materi matematika (Gunawan, 2018). Hal ini berarti soal cerita berbentuk sebuah permasalahan dalam kehidupan sehari-hari yang disajikan dalam cerita pendek (Miviani et al., 2020). Sehingga soal cerita matematika merupakan soal yang disajikan dalam cerita pendek yang mengandung konsep-konsep matematika dan mempunyai makna yang diambil dari permasalahan-permasalahan dalam kehidupan sehari-hari.

Soal cerita dalam matematika disajikan dalam bentuk kalimat sehari-hari dan umumnya mengaplikasikan konsep matematika. Jadi pada dasarnya soal cerita merupakan salah satu bentuk soal yang disajikan atau dibentuk menggunakan bahasa verbal dimana biasanya masalah yang terkandung dalam soal tersebut adalah masalah data kehidupan sehari-hari. Langkah-langkah yang digunakan untuk pengerjaan soal cerita yaitu, (a) menentukan hal yang diketahui dalam soal, (b) menentukan hal yang ditanyakan dalam soal, (c) membuat model matematika (kalimat matematika), serta (d) melakukan komputasi (perhitungan, dan mengintepretasi jawaban model ke permasalahan soal semula) (Kaprinaputri, 2013).

Latar belakang pemilihan soal cerita diantaranya kendala yang dihadapi siswa sekolah dasar dalam pembelajaran matematika yaitu dalam mengerjakan soal cerita (Laili \& Tristiana, 2016). Pada penyelesaian soal cerita, peserta didik tidak hanya dituntut untuk memiliki keterampilan dalam berhitung saja, namun juga memperhatikan proses penyelesaiannya. Diharapkan peserta didik menyelesaikan soal cerita melalui tahap demi tahap sehingga guru mampu menganalisis kemampuan yang telah mereka miliki. Kemampuan yang dimaksud terutama pemahaman peserta didik terhadap konsep yang digunakan dalam menyelesaikan soal cerita yang diberikan. Selain itu soal cerita memegang peranan yang sangat penting dalam kehidupan sehari-hari siswa, karena soal cerita mengedepankan masalah nyata yang sesuai dengan kehidupan sehari-hari sehingga sangat tepat digunakan untuk mendekatkan siswa dengan budaya lokal di sekitarnya (Purwoko et al., 2019). Budaya lokal yang terdapat di Desa Sukodono, Kecamatan Donorojo, Kabupaten Pacitan, Provinsi Jawa Timur yang dimaksud dalam penelitian ini yaitu kerajinan batu akik.

Unsur budaya lokal diangkat dari lingkungan kemudian diintegrasikan ke dalam pembelajaran melalui studi etnomatematika. Etnomatematika adalah suatu kajian yang meneliti cara sekelompok orang pada budaya tertentu dalam memahami, mengekspresikan, dan menggunakan konsep-konsep serta praktikpraktik kebudayaannya yang digambarkan oleh peneliti sebagai sesuatu yang matematis (Barton, 1996). Etnomatematika juga didefinisikan sebagai matematika yang dilakukan oleh para anggota kelompok yang berbeda budaya, yang diidentifikasi sebagai masyarakat adat, kelompok pekerja, kelas profesional, dan kelompok anakanak dari kelompok usia tertentu, dll (D’Ambrosio, 1985). François (2012) menambahkan perluasan penggunaan etnomatematika yang sesuai dengan keanekaragaman budaya siswa dan dengan praktik matematika dalam keseharian mereka membawa matematika lebih dekat dengan lingkungan siswa karena etnomatematika secara implisit merupakan program atau kegiatan yang menghantarkan nilai-nilai dalam matematika dan pendidikan matematika.

Etnomatematika batu akik memuat unsur budaya yang dapat digali dari kerajinan batu akik ke dalam materi pembelajaran matematika. Selain ke dalam materi geometri, unsur etnomatematika batu akik juga dapat diintegrasikan ke dalam materi operasi hitung bilangan bulat.

E-LKPD telah diujicobakan dengan hasil yaitu keseluruhan tahapan pemecahan masalah berada pada kategori tinggi. Dengan demikian eLKPD dapat digunakan sebagai bahan ajar alternatif selama pembelajaran jarak jauh, dapat 
digunakan untuk meningkatkan kemampuan siswa dalam menyelesaikan masalah matematika, sekaligus mendekatkan siswa dengan budaya lokal. Tingginya tingkat kemampuan pemecahan masalah, akan berbanding lurus dengan hasil belajar siswa (Badrulaini, 2018).

Hasil belajar adalah kompetensi dan keterampilan yang dimiliki siswa setelah ia menerima pengalaman belajarnya (Mølstad \& Karseth, 2016; Sudjana, 2011). Kemampuan peserta didik dalam menyerap atau memahami materi yang telah diajarkan dapat diketahui berdasarkan penilaian yang dilakukan oleh guru. Bukti dari usaha yang dilakukan dalam proses belajar adalah hasil belajar yang diukur melalui tes. Jadi dapat disimpulkan bahwa hasil belajar yaitu kecakapan yang dicapai dalam suatu usaha, dalam hal ini usaha belajar dalam perwujudan hasil belajar. Hasil belajar tercermin dari perubahan tingkah laku dan kemampuan belajar siswa.

Tinggi rendahnya pencapaian hasil belajar dipengaruhi oleh faktor internal dan faktor eksternal. Faktor internal diantaranya meliputi kemampuan awal, tingkat kecerdasan, motivasi belajar, kebiasaan belajar, kecemasan belajar, motivasi belajar, dan sebagainya, sedangkan faktor eksternal meliputi lingkungan keluarga, lingkungan sekolah, lingkungan masyarakat, keadaan sosial ekonomi, dan sebagainya (Lestari, 2017). Lebih lanjut Lestari (2017) menyebutkan bahwa kemampuan awal peserta didik memiliki pengaruh yang cukup besar terhadap hasil belajar siswa.

Kemampuan awal peserta didik merupakan salah satu faktor penentu dalam keberhasilan pembelajaran matematika. Setiap individu mempunyai kemampuan belajar yang berlainan. Kemampuan awal peserta didik adalah kemampuan yang telah dipunyai oleh peserta didik sebelum ia mengikuti pembelajaran yang akan diberikan. Kemampuan awal (entry behavior) ini menggambarkan kesiapan peserta didik dalam menerima pelajaran yang akan disampaikan oleh guru (Russefendi, 2004).

Berangkat dari latar belakang tersebut, peneliti bermaksud melakukan penelitian lanjutan terkait kemampuan awal dan hasil belajar siswa setelah menyelesaikan soal cerita pada e-LKPD berbasis etnomatematika batu akik. Oleh karena itu penelitian ini bertujuan untuk mengetahui efektivitas e-LKPD berbasis etnomatematika batu akik ditinjau dari kemampuan awal siswa.

\section{Metode Penelitian}

Penelitian ini menggunakan eksperimen semu. Rancangan eksperimen Semu (quasi eksperimen) adalah rancangan penelitian eksperimen yang dilakukan pada kondisi yang tidak memungkinkan mengontrol atau memanipulasikan semua variabel yang relevan (Danim, 2003). Lebih lanjut, Danim (2003) menyebutkan penelitian eksperimen adalah penelitian dalam melakukan sebuah studi yang obyektif, sistematis, dan terkontrol untuk memprediksi atau mengontrol fenomena. Penelitian eksperimen bertujuan untuk menyelidiki hubungan sebab akibat, dengan cara mengekspos satu atau lebih kelompok eksperimental dan satu atau lebih kondisi eksperimen. Hasilnya dibandingkan dengan satu atau lebih kelompok kontrol yang tidak dikenai perlakuan. Desain penelitian ini berbentuk randomized pretest-posttest Control Group Design, yaitu desain kelompok kontrol pretespostes yang melibatkan dua kelompok dan pengambilan sampel dilakukan secara acak.

Penelitian dilaksanakan pada semeter genap tahun pelajaran 2020/2021. Penelitian ini melibatkan siswa kelas IV SD Negeri Sukodono 1 dan SD Negeri Sukodono 2 sebagai populasi penelitian, sedangkan sampel penelitian ditetapkan melalui teknik purposive sampling. Adapun sampel penelitiannya yaitu masingmasing 15 siswa dari kedua kelas yang terdiri dari 5 siswa pada setiap kategori kemampuan awal siswa. sedangkan obyek penelitiannya adalah kemampuan awal siswa dan hasil belajar matematika yang melaksanakan pembelajaran dengan menggunakan e-LKPD berbasis etnomatematika batu akik dan e-LKPD konvensional.

Teknik pengumpulan data yang digunakan adalah teknik dokumentasi dan teknik 
tes. Teknik dokumentasi digunakan untuk mengumpulkan data kemampuan awal yang diperoleh dari nilai matematika pada laporan hasil belajar peserta didik semester gasal tahun pelajaran 2020/2021. Teknik tes digunakan untuk mengumpulkan data hasil belajar matematika. Tes hasil belajar berbentuk soal cerita sebanyak 5 soal. Uji coba instrumen yang dilakukan meliputi uji validitas item dan uji reliabilitas. Dari 5 soal yang diujicobakan, seluruhnya termasuk valid dan reliabel.

Analisis data menggunakan anava dua faktor, faktor pertama (faktor A) adalah jenis eLKPD (e-LKPD berbasis etnomatematika dan eLKPD konvensional). LKPD konvensional merupakan LKPD yang tinggal pakai, tinggal beli, instan, serta tanpa upaya merencanakan, menyiapkan, dan menyusun sendiri (Prastowo, 2012:18). Faktor kedua (faktor B) yaitu tingkat kemampuan awal siswa (tinggi, sedang, dan rendah). Sebelum menganalisis data hasil belajar, terlebih dahulu akan dilakukan uji prasyarat analisis yang meliputi uji keseimbangan data kemampuan awal, uji normalitas, dan uji homogenitas. Langkah-langkah analisis data yaitu merumuskan hipotesis, menentukan taraf signifikansi $(\alpha=5 \%)$, menghitung $F$ rasio, membandingkan $\mathrm{F}$ rasio dengan $\mathrm{F}$ tabel, dan penarikan kesimpulan.

\section{Hasil dan Pembahasan}

Penelitian ini merupakan penelitian ekseprimen semu yang dilakukan terhadap siswa kelas IV dari SDN Sukodono 1 dan SDN Sukodono 2 Kabupaten Pacitan pada semester genap tahun pelajaran 2020/2021. Siswa kelas IV SDN Sukodono 2 sebagai kelompok kontrol, sedangkan siswa kelas IV dari SDN Sukodono 1 sebagai kelompok eksperimen. Kelompok eksperimen mendapat perlakuan pembelajaran dengan menggunakan e-LKPD berbasis etnomatematika batu akik, sementara kelompok kontrol menggunakan e-LKPD konvensional. ELKPD konvensional yang digunakan pada penelitian ini yaitu berupa Lembar Kerja Siswa (LKS) yang biasa digunakan dalam pembelajaran pada SDN 1 Sukodono dan SDN 2 Sukodono. Gambar 1 dan Gambar 2 berikut merupakan tampilan dua jenis e-LKPD yang digunakan pada penelitian.
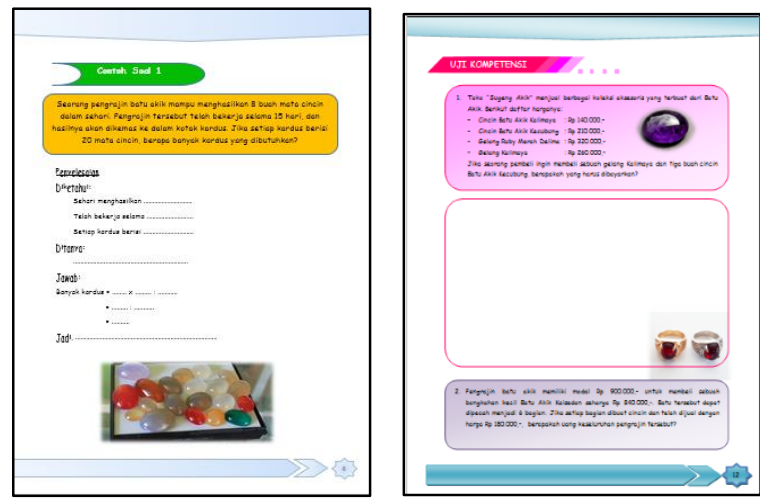

Gambar 1. E-LKPD berbasis etnomatematika
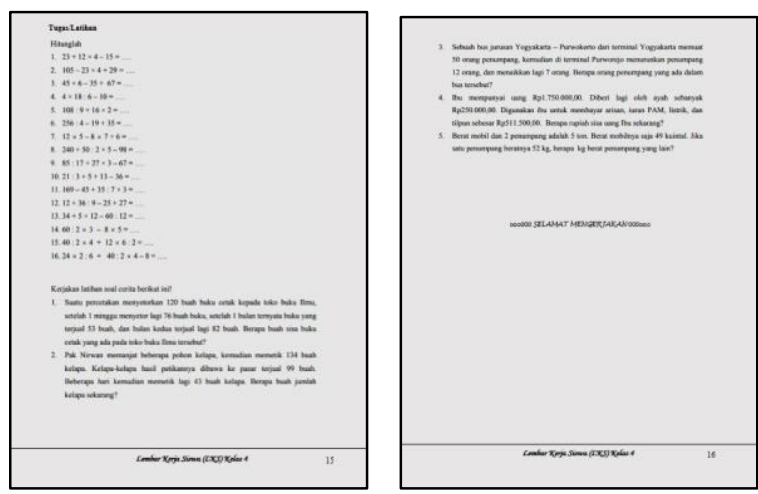

Gambar 2. E-LKPD konvensional

Kemampuan awal siswa dibedakan menjadi kategori tinggi, sedang, dan rendah. Dari hasil pengumpulan data, masing-masing kategori pada setiap kelas diambil sampel secara acak sebanyak 5 siswa. Uji prasyarat penelitian meliputi uji keseimbangan, uji normalitas, dan uji homogenitas. Hasil analisis uji prasyarat dan uji hipotesis dijabarkan sebagai berikut.

\section{Uji Keseimbangan}

Uji keseimbangan yang ditinjau dari kemampuan awal siswa melalui uji-t memperoleh hasil dengan nilai Sig $>\alpha$, yaitu $0.389>0.05$ hasil uji-t tersebut menunjukkan bahwa kemampuan awal siswa pada kelas eksperimen dan kelas kontrol dalam keadaan seimbang.

\section{Uji Normalitas}

Uji normalitas dilakukan terhadap data kemampuan awal dan data hasil belajar siswa. 
Data kemampuan awal menunjukkan nilai Sig > $\alpha$, yaitu $0.074>0.05$. Hasil tersebut menunjukkan bahwa data kemampuan awal berasal dari populasi yang berdistribusi normal. Sedangkan untuk data hasil belajar menunjukkan nilai Sig > $\alpha$, yaitu $0.061>0.05$, sehingga

Dapat disimpulkan bahwa data hasil belajar berasal dari populasi yang berdistribusi normal.

\section{Uji homogenitas}

Uji homogenitas juga dilakukan terhadap data kemampuan awal dan data hasil belajar siswa. Data kemampuan awal menunjukkan nilai Sig $>\alpha$, yaitu $0.137>0.05$ sehingga dapat ditarik kesimpulan bahwa data kemampuan awal kelas ekperimen dan kelas kontrol mempunyai variansi homogen. Selanjutnya data hasil belajar siswa menunjukkan nilai $\operatorname{Sig}>\alpha$, yaitu $0.763>0.05$, sehingga dapat disimpulkan bahwa data hasil belajar kelas ekperimen dan kelas kontrol mempunyai variansi homogen.

\section{Uji Hipotesis}

Pengujian hipotesis pada penelitian ini menggunakan analisis variansi dua jalur dengan sel sama. Adapun hipotesis nol yang akan diuji adalah:

$\mathrm{H}_{01}$ : tidak ada efek faktor jenis e-LKPD di dalam eksperimen

$\mathrm{H}_{02}$ : tidak ada efek faktor kemampuan awal di dalam eksperimen

$\mathrm{H}_{03}$ : tidak ada efek interaksi antara faktor jenis eLKPD dan faktor kemampuan awal

Kriteria pada pengujian hipotesis yaitu $H_{0}$ ditolak jika $t_{\text {hitung }}>t_{\text {tabel }}$ pada taraf signifikansi $\alpha=0,05$. Ringkasan hasil analisis varian dua jalur disajikan pada Tabel 1.

Tabel 1.

Ringkasan tabel anava

\begin{tabular}{|c|c|l|l|c|c|}
\hline Sumber variansi & dk & \multicolumn{1}{|c|}{ JK } & \multicolumn{1}{|c|}{ KT } & F hit $_{\text {hit }}$ & F trb \\
\hline Rata-rata & 1 & 1921282,13 & 1921282,13 & & \\
\hline Jenis e-LKPD & 1 & 10378,80 & 10378,80 & 4,91 & 4,26 \\
\hline Kemampuan awal & 2 & 35956,87 & 17978,44 & 8,50 & 3,40 \\
\hline Interaksi & 2 & 1644,2 & 822,1 & 0,39 & 3,40 \\
\hline Error & 24 & 50758 & 2114,92 & & \\
\hline Jumlah & 29 & 2020020 & & & \\
\hline
\end{tabular}

Kesimpulan:

1. Faktor jenis e-LKPD diperoleh hasil $t_{\text {hit }}>$ $t_{\text {tab }}$ yaitu 4,91 > 4,26 dengan demikian $H_{0}$ ditolak, artinya ada efek faktor jenis e-LKPD terhadap hasil belajar siswa.

2. Faktor kemampuan awal diperoleh hasil $t_{\text {hit }}>t_{t a b}$ yaitu $8,50>3,40$ dengan demikian $H_{0}$ ditolak, artinya ada efek faktor kemampuan awal terhadap hasil belajar siswa.

3. Interaksi antara faktor jenis e-LKPD dan kemampuan awal diperoleh hasil $t_{\text {hit }}<t_{t a b}$ yaitu 0,39>3,40 dengan demikian $H_{0}$ diterima, artinya tidak ada efek interaksi antara faktor jenis e-LKPD dan kemampuan awal terhadap hasil belajar siswa.

Berdasarkan hasil uji Anava dua jalur diperoleh kesimpulan bahwa terdapat perbedaan yang signifikan pada hasil belajar siswa berdasarkan jenis e-LKPD dan tingkat kemampuan awal siswa. Hal ini didukung pula dengan nilai rataan marjinal dari masing masing jenis e-LKPD, yaitu mean e-LKPD berbasis etnomatematika lebih besar dari pada mean eLKPD konvensional. Oleh karena itu dapat disimpulkan bahwa pembelajaran dengan menggunakan e-LKPD atau bahan ajar berbasis etnomatematika lebih efektif dibandingkan dengan pembelajaran menggunakan e-LKPD atau bahan ajar biasa. Hal ini senada dengan hasil penelitian Utami et al. (2018) yang menyatakan bahwa modul berbasis etnomatematika dapat meningkatkan kemampuan pemecahan masalah. Nasryah \& Rahman (2020) juga menguatkan hal tersebut di mana pembelajaran dengan pendekatan etnomatematika berpengaruh secara signifikan terhadap kemampuan pemecahan masalah dan motivasi belajar siswa sekolah dasar.

Pada penelitian ini kedua kelompok subjek diberikan perlakuan yang berbeda pada kegiatan pembelajarannya, yakni pada kelas eksperimen menggunakan e-LKPD berbasis etnomatematika batu akik, sementara kelompok kontrol menggunakan e-LKPD konvensional. ELKPD berbasis etnomatematika batu akik merupakan lembar kegiatan siswa berbentuk 
elektronik (soft file) yang digunakan selama pembelajaran daring (Setiana, dkk, 2021). Selama pembelajaran daring siswa melaksanakan pembelajaran secara virtual, dalam penelitian ini pelaksanaan pembelajaran menggunakan platform google meet dan Whatsapp. E-LKPD dapat diunduh siswa melalui smartphone, komputer, tablet, laptop, maupun alat komunikasi lain yang mendukung. Setelah mengunduh eLKPD siswa dapat menyelesaikan soal atau permasalahan yang diberikan dan menuliskan langkah penyelesaian soal pada buku tulis masing-masing. Perbedaan terletak pada unsur budaya yang termuat di dalamnya. Pada e-LKPD berbasis etnomatematika batu akik, terdapat bacaan singkat terkait sejarah batu akik, gambar jenis-jenis batu akik, materi pelajaran dan soal cerita kontekstual berbasis etnomatematika batu akik. Soal cerita disusun dengan tahapan penyelesaian soal secara lengkap, meliputi tahapan: menentukan apa yang diketahui dalam soal, menentukan apa yang ditanyakan dalam soal, merumuskan rencana pemecahan masalah dengan menyusun model matematika, menyelesaikan masalah, dan menuliskan kesimpulan.

Pada pelaksanaan pembelajaran daring, guru menstimulasi siswa untuk menyelesaikan soal cerita sesuai tahapan penyelesaian soal melalui e-LKPD. Kedua kelas subjek penelitian diberikan pembelajaran dengan tahapan yang sama, hanya berbeda pada jenis e-LKPD. Pembelajaran daring dilaksanakan sebanyak dua pertemuan untuk masing-masing kelas. Setelah dilaksanakan pembelajaran kemudian dilaksanakan pengambilan data melalui tes. Soal tes berupa soal cerita sebanyak 5 butir soal. Hasil tes ditinjau dari tahapan penyelesaian masalah dituangkan pada Tabel 2.

Berdasarkan Tabel 2 diketahui bahwa pada kedua kelas penelitian terdapat perbedaan hasil yang cukup signifikan. Rata-rata nilai berdasarkan tahapan penyelesaian masalah pada kelas eksperimen relatif lebih tinggi dibandingkan dengan rata-rata nilai dari kelas kontrol.
Tabel 2.

Data kemampuan menyelesaikan soal cerita

\begin{tabular}{|c|l|c|c|}
\hline No & \multicolumn{2}{|c|}{$\begin{array}{c}\text { Tahapan penyelesaian soal } \\
\text { cerita }\end{array}$} & \multicolumn{2}{|c|}{ Rata-rata nilai } \\
\cline { 3 - 4 } & \multicolumn{1}{|c|}{ Eksperimen } & Kontrol \\
\hline 1 & $\begin{array}{l}\text { menentukan apa yang } \\
\text { diketahui dalam soal }\end{array}$ & 87,68 & 80,65 \\
\hline 2 & $\begin{array}{l}\text { menentukan apa yang } \\
\text { ditanyakan dalam soal }\end{array}$ & 89,71 & 73,46 \\
\hline 3 & menyusun model matematika & 79,92 & 65,84 \\
\hline 4 & $\begin{array}{l}\text { komputasi/menghitung hasil } \\
\text { akhir }\end{array}$ & 77,49 & 63,06 \\
\hline 5 & menuliskan kesimpulan & 80,27 & 80,43 \\
\hline & \multicolumn{1}{|c|}{ Rata-rata } & 83,01 & 73,69 \\
\hline
\end{tabular}

Seluruh tahapan penyelesaian soal cerita pada kelompok eksperimen termasuk pada kriteria tinggi, sedangkan pada kelompok kontrol terdapat dua tahapan yang termasuk dalam kriteria sedang yakni tahapan menyusun model matematika dan tahapan komputasi. Hal ini mengindikasikan bahwa e-LKPD berbasis etnomatematika lebih efektif dalam meningkatkan kemampuan pemecahan masalah matematika, sebagaimana hasil penelitian (Imswatama \& Lukman, 2018) I yang menyimpulkan bahwa penggunaan bahan ajar matematika berbasis etnomatematika lebih baik dari pada pembelajaran yang tidak menggunakan bahan ajar matematika berbasis etnomatematika.

Temuan dalam penelitian ini yaitu hasil belajar siswa yang mendapatkan pembelajaran menggunakan e-LKPD berbasis etnomatematika batu akik relatif lebih baik daripada siswa yang menggunakan e-LKPD konvensional, atau dengan kata lain e-LKPD berbasis etnomatematika batu akik lebih efektif dibandingkan dengan e-LKPD konvensional. Penerapan e-LKPD berbasis etnomatematika batu akik memberikan pengalaman yang baru bagi peserta didik untuk mempelajari matematika dengan mengaitkan materi pelajaran dengan halhal berkenaan dengan budaya (Andriyani \& E, 2017; Fauzi et al., 2020). Budaya yang dimaksud di sini yaitu budaya yang ada di lingkungan sekitar siswa terutama yang berhubungan dengan batu akik. Oleh karena itu kelebihan e-LKPD berbasis etnomatematika batu akik dapat dijabarkan menjadi beberapa poin berikut. 
Kelebihan e-LKPD berbasis etnomatematika batu akik yang pertama yaitu eLKPD berbasis kontekstual (Abi, 2017; Firdaus \& Rustina, 2019). Bahan ajar yang berbasis kontekstual menghubungkan materi pelajaran dengan dunia nyata serta dapat membuat hubungan-hubungan antara pembelajaran dengan kehidupan sehari-hari (Hamruni, 2015). Dengan mengaitkan pembelajaran pada dunia nyata dapat melibatkan siswa untuk menemukan makna dari pengetahuan yang sedang mereka pelajari. Dengan pendekatan kontekstual pada bahan ajar yang digunakan dalam pembelajaran maka kegiatan belajar yang dilaksanakan akan menjadi lebih bermakna (Fajriyah, 2018). Dengan kebermaknaan yang diperoleh siswa berimplikasi terhadap peningkatan pemahaman konsep siswa (Arifah \& Saefudin, 2017). Dengan pemahaman konsep tersebut sehingga hasil belajar siswa relatif meningkat dan lebih baik dibandingkan dengan siswa yang menggunakan e-LKPD konvensional.

Kelebihan lain dari e-LKPD berbasis etnomatematika batu akik yaitu konten e-LKPD yang memuat berbagai hal terkait batu akik meningkatkan ketertarikan siswa untuk mempelajarinya serta meningkatkan rasa ingin tahu siswa (Khairida, 2019). Ketertarikan dan rasa ingin tahu siswa tersebut terkait dengan minat belajar siswa. Dengan meningkatnya minat belajar siswa secara linear akan meningkatkan hasil belajar siswa (Nurhasanah \& Sobandi, 2016). Hal ini sesuai dengan pendapat Khairida (2019) yaitu dengan minat belajar yang baik akan berdampak positif pada aspek kognitif siswa terutama dalam aplikasi, pengetahuan dan pemahaman.

E-LKPD berbasis etnomatematika merupakan bentuk elektronik dari LKPD berbasis etnomatematika. Dengan adanya bahan ajar berbentuk elektronik memudahkan siswa dalam mempelajari materi ajar selama pembelajaran daring. Siswa dapat mengunduh e-LKPD melalui alat komunikasi masing-masing kemudian siswa dapat menuliskan jawabannya pada buku tulis. Dengan adanya LKPD berbentuk elektronik dan berbasis etnomatematika ini menjadikan siswa lebih termotivasi untuk mengikuti pembelajaran dan mempelajari materi secara mandiri. Hal ini sejalan dengan penelitian Fajriyah (2018) yang menyatakan bahwa etnomatematika memunculkan kearifan budaya yang mana mampu memotivasi peserta didik dalam pembelajaran matematika.

Di samping faktor jenis e-LKPD, yang menjadi fokus pada penelitian ini yaitu faktor kemampuan awal siswa. Kemampuan awal dalam penelitian ini dibedakan menjadi tinggi, sedang, dan rendah. Kemampuan awal merupakan kemampuan yang telah dimiliki siswa sebelum mengikuti pembelajaran. Kemampuan awal dapat dikatakan sebagai prasyarat yang harus dimiliki siswa untuk mempelajari materi pembelajaran berikutnya yang lebih kompleks. Hasil penelitian ini menunjukkan bahwa kemampuan awal berpengaruh terhadap hasil belajar siswa. Dengan demikian dapat disimpulkan bahwa siswa dengan kemampuan awal yang baik akan lebih mudah dalam memahami materi sehingga dapat mencapai hasil belajar yang lebih baik (Firmansyah, 2017; Lestari, 2017). Hal ini juga dikuatkan oleh hasil penelitian Sari et al. (2021) bahwa peserta didik dengan kemampuan matematika tinggi (dalam hal ini kemampuan awal matematika) memenuhi indikator kemampuan literasi matematis, diantaranya yaitu mampu melaksanakan prosedur dalam memecahkan masalah dengan jelas, termasuk prosedur yang memerlukan keputusan secara berurutan dan mampu menyelesaikan masalah dengan menggunakan strategi yang sederhana. Tidak jauh berbeda dengan hasil penelitian tersebut, Nurdin et al. (2020) juga menyebutkan bahwa kemampuan awal matematis (KAM) berperan dalam perkembangan kemampuan berpikir kritis siswa, sehingga dapat dikatakan KAM berpengaruh pula terhadap hasil belajar.

\section{Kesimpulan}

Hasil penelitian analisis efektivitas eLKPD berbasis etnomatematika batu akik ditinjau dari kemampuan awal siswa menunjukkan bahwa e-LKPD berbasis etnomatematika batu akik lebih efektif 
daripada e-LKPD konvensional; hasil belajar siswa dengan tingkat kemampuan awal tinggi lebih baik daripada siswa yang memiliki kemampuan awal sedang dan rendah; dan tidak ada interaksi antara jenis e-LKPD dan tingkat kemampuan awal siswa ditinjau dari hasil belajar matematika siswa.

Kelebihan e-LKPD berbasis etnomatematika batu akik yaitu hasil belajar siswa yang mendapatkan pembelajaran menggunakan e-LKPD berbasis etnomatematika batu akik relatif lebih baik daripada siswa yang menggunakan e-LKPD konvensional, e-LKPD berbasis etnomatematika batu akik memberikan pengalaman yang baru bagi peserta didik untuk mempelajari matematika dengan mengaitkan materi pelajaran dengan hal-hal berkenaan dengan budaya, e-LKPD berbasis kontekstual sehingga pembelajaran menjadi lebih bermakna, e-LKPD berbasis etnomatematika batu akik meningkatkan minat belajar siswa, e-LKPD berbasis etnomatematika batu akik memunculkan kearifan budaya yang mana mampu memotivasi peserta didik dalam pembelajaran matematika.

Penelitian ini memiliki keterbatasan yang dapat dijadikan bahan pertimbangan bagi peneliti berikutnya. Penelitian ini hanya terbatas pada materi operasi hitung campuran, di samping itu subjek uji coba hanya berasal dari dua sekolah, sehingga perlu diujicobakan pada ruang lingkup yang lebih luas.

\section{Ucapan Terimakasih}

Artikel ini merupakan publikasi hasil penelitian dengan skema Penelitian Terapan Unggulan Universitas Sarjanawiyata Tamansiswa Tahun 2021 menggunakan dana yang bersumber dari LP3M UST. Oleh karena itu penulis mengucapkan terimakasih kepada LP3M UST atas dukungan pendanaannya demi kesuksesan penelitian ini.

\section{Referensi}

Abi, A. M. (2017). Integrasi etnomatematika dalam kurikulum matematika sekolah. JPMI (Jurnal Pendidikan Matematika Indonesia), $\quad 1(1), \quad 1-6$. https://doi.org/10.26737/jpmi.v1i1.75

Andriyani, \& E, K. (2017). Etnomatematika : model baru dalam pembelajaran. Jurnal Gantang, II(2), 133-144.

Arifah, U., \& Saefudin, A. A. (2017). Menumbuhkambangkan kemampuan pemahaman konsep matematika dengan menggunakan model pembelajaran Guided Discovery. UNION: Jurnal Ilmiah Pendidikan Matematika, 5(3), 263-272. https://doi.org/10.30738/.v5i3.1251

Badrulaini, B. (2018). Hubungan kemampuan pemecahan masalah dan kemandirian belajar terhadap hasil belajar matematika peserta didik. Jurnal Pendidikan Tambusai, 2(4), 847-855.

Barton, B. (1996). Ethnomathematics: exploring cultural diversity in Mathematics Semantic Scholar. https://www.semanticscholar.org/paper/ Ethnomathematics\%3A-ExploringCultural-Diversity-inBarton/a9b9405846d71a9b5e12e1693e $750 \mathrm{ac} 722070622$

D'Ambrosio, U. (1985). Ethnomathematics and its place in the history and pedagogy of mathematics. For the Learning of Mathematics, 5(1), 44-48.

Danim, S. (2003). Sejarah dan Metodologi. EGC.

Fajriyah, E. (2018). Peran etnomatematika terkait konsep matematika dalam mendukung literasi. PRISMA: Prosiding Seminar Nasional Matematika, 1, 114119.

Fauzi, A., Rahmatih, A. N., Sobri, M., Radiusman, R., \& Widodo, A. (2020). Etnomatematika: Eksplorasi budaya sasak sebagai sumber belajar matematika Sekolah Dasar. Jurnal Review Pembelajaran Matematika, 5(1), $1-13$. 
https://doi.org/10.15642/jrpm.2020.5.1. $1-13$

Firdaus, N., \& Rustina, R. (2019). Analisis kemampuan berpikir kritis matematis ditinjau dari gaya belajar. Prosiding Seminar Nasional \& Call For Papers Program Studi Magister Pendidikan Matematika Universitas Siliwangi, 432437.

http://jurnal.unsil.ac.id/index.php/sncp/a rticle/download/1071/731

Firmansyah, M. A. (2017). Peran kemampuan awal matematika dan belief matematikaterhadap hasil belajar. Prima: Jurnal Pendidikan Matematika, 1(1), 55-68. https://doi.org/10.31000/prima.v1i1.255

François, K. (2012). Ethnomathematics in a european context: Towards an enriched meaning of ethnomathematics. Journal of Mathematics and Culture, 6(1), 191208.

Gunawan, A. (2018). Analisis kesalahan dalam menyelesaikan soal cerita pada mata pelajaran matematika siswa kelas V SDN 59 kota Bengkulu. Jurnal PGSD, 9(2), 216-225. https://doi.org/10.33369/pgsd.9.2.216225

Hamruni, H. (2015). Konsep dasar dan implementasi pembelajaran kontekstual. Jurnal Pendidikan Agama Islam, 12(2), 177-188. https://doi.org/10.14421/jpai.2015.12204

Imswatama, A., \& Lukman, H. S. (2018). Penerapan bahan ajar matematika berbasis etnomatematika terhadap kemampuan pemecahan masalah matematis siswa. Prosiding SENAMKU, $1,92-100$.

Kaprinaputri, A. P. (2013). Kemampuan menyelesaikan soal cerita matematika. JIV, $8(1), \quad 10-15$. https://doi.org/10.21009/jiv.0801.2

Kemdikbud. (2020). Pembelajaran dimasa Covid-19.

https://www.kemdikbud.go.id/main/file s/download/c4c7ec76db850c3
Khairida. (2019). Penerapan pendekatan pembelajaran berbasis etnomatematika dalam meningkatkan minat belajar dan aspek kognitif siswa. Jurnal Pendidikan Dan Pembelajaran Terpadu, 1(2), 114124.

https://doi.org/https://doi.org/10.32696/ pgsd.v1i2.365

Laili, N. H., \& Tristiana, D. (2016). Pengembangan media pembelajaran soal cerita dengan cerpen pada materi operasi hitung campuran untuk siswa kelas IV SDN Sumberkerep tahun ajaran 2012/2013. In SAINTIS (Vol. 8, Issue 2).

Lestari, W. (2017). Pengaruh kemampuan awal matematika dan motivasi belajar terhadap hasil belajar matematika. Jurnal Analisa, 3(1), 76-84. https://doi.org/10.15575/ja.v3i1.1499

Miviani, H., Darmono, P. B., \& purwaningsih, W. I. (2020). Analisis kemampuan literasi matematis siswa dalam menyelesaikan soal cerita matematika pada siswa SMP. Prosiding , 6(2).

Mølstad, C. E., \& Karseth, B. (2016). National curricula in Norway and Finland: The role of learning outcomes. European Educational Research Journal, 15(3), 329-344. https://doi.org/10.1177/1474904116639 311

Nasryah, C. E., \& Rahman, A. A. (2020). Pengaruh pendekatan etnomatematika terhadap kemampuan pemecahan masalah matematis dan motivasi siswa SD di Aceh Barat. MAJU: Jurnal Ilmiah Pendidikan Matematika, 7(1), 126-140. https://ejournal.stkipbbm.ac.id/index.ph $\mathrm{p} / \mathrm{mtk} /$ article/view/512

Nurdin, E., Nayan, D. D., \& Risnawati, R. (2020). Pengaruh pembelajaran model creative problem solving (CPS) terhadap kemampuan berpikir kritis ditinjau dari kemampuan awal matematis siswa sekolah menengah atas. Jurnal Gantang, 5(1). https://doi.org/10.31629/jg.v5i1.2151

Nurhasanah, S., \& Sobandi, A. (2016). Minat 
belajar sebagai determinan hasil belajar siswa. Jurnal Pendidikan Manajemen Perkantoran, $1(1)$. https://doi.org/10.17509/jpm.v1i1.3264 Purwoko, R. Y., Astuti, E. P., Arti, M. S., \& Widiyono, Y. (2019). Batik Nusantara pattern in design of mathematical learning model for elementary school. Journal of Physics: Conference Series, 1254(1). https://doi.org/10.1088/17426596/1254/1/012001

Russefendi, E. (2004). Pengajaran matematika modern. Tarsito.

Sari, E. K., Sugiyanti, S., \& Pramasdyahsari, A. S. (2021). Profil kemampuan literasi matematis siswa berkemampuan matematika tinggi dalam menyelesaikan soal cerita berbasis PISA. Jurnal Gantang, 6(1), 83-92. https://doi.org/10.31629/jg.v6i1.3286

Setyorini, I. (2020). Pandemi Covid-19 dan online learning: Apakah berpengaruh terhadap proses pembelajaran pada Kurukulum 13 ? Jiemar, O1(Juni), 95102.

Sudjana, N. (2011). Penilaian hasil proses belajar mengajar. Remaja Rosdakarya.

Utami, R. E., Nugroho, A. A., Dwijayanti, I., \& Sukarno, A. (2018). Pengembangan emodul berbasis etnomatematika untuk meningkatkan kemampuan pemecahan masalah. JNPM (Jurnal Nasional Pendidikan Matematika), 2(2), 268-283. https://doi.org/10.33603/jnpm.v2i2.145 